Margareth Guimarães Lima'

Marilisa Berti de Azevedo

Barros"

Chester Luiz Galvão César'II

Moisés Goldbaum ${ }^{\text {IV }}$

Luana Carandina $v$

Maria Cecília Goi Porto Alves ${ }^{\mathrm{vI}}$

\section{Health-related behavior and quality of life among the elderly: a population-based study}

\section{Comportamentos relacionados a saúde e qualidade de vida em idosos: um estudo de base populacional}

Programa de Pós-Graduação do Departamento de Medicina Preventiva e Social. Faculdade de Ciências Médicas (FCM). Universidade Estadual de Campinas (Unicamp). Campinas, SP, Brasil

" Departamento de Medicina Preventiva e Social. FCM-Unicamp. Campinas, SP, Brasil

III Departamento de Epidemiologia. Faculdade de Saúde Pública. Universidade de São Paulo (USP). São Paulo, SP, Brasi

IV Departamento de Medicina Preventiva. Faculdade de Medicina. USP. São Paulo SP, Brasil

Departamento de Saúde Pública. Faculdade de Medicina. Universidade Estadual Paulista. Botucatu, SP, Brasil

vi Secretaria do Estado de Saúde de São Paulo. São Paulo, SP, Brasil

Correspondence:

Margareth Guimarães Lima

UNICAMP

Caixa postal 6111

13083-970 Campinas, SP, Brasil

E-mail: margareth.guimaraes@yahoo.com.br

Received: $7 / 24 / 2010$

Approved: 1/19/2011

Article available from: www.scielo.br/rsp

\section{ABSTRACT}

OBJECTIVE: To assess the association between health-related behaviors and quality of life among the elderly.

METHODS: A population-based cross-sectional study was carried out including 1,958 elderly living in four areas in the state of São Paulo, southeastern Brazil, 2001/2002. Quality of life was assessed using the Medical Outcomes Study SF-36-Item Short Form Health Survey instrument. This instrument's eight subscales and two components were the dependent variables. Independent variables were physical activity, weekly frequency of alcohol consumption and smoking. Multiple linear regression models were used to control for the effect of gender, age, schooling, work, area of residence and number of chronic conditions.

RESULTS: Physical activity was positively associated with the eight SF-36 subscales. The stronger associations were found for role-physical $(\beta=11.9)$, physical functioning $(\beta=11.3)$ and physical component. Elderly individuals who consumed alcohol at least once a week showed a better quality of life than those did not consume alcohol. Compared to non-smokers, smokers had a poorer quality of life for the mental component $(\beta=-2.4)$.

CONCLUSIONS: The study results showed that physical activity, moderate alcohol consumption and no smoking are positively associated with a better quality of life in the elderly.

DESCRIPTORS: Aged. Quality of Life. Life Style. Health Knowledge, Attitudes, Practice. Cross-Sectional Studies. 


\section{RESUMO}

OBJETIVO: Analisar a associação de comportamentos saudáveis com a qualidade de vida relacionada à saúde em idosos.

MÉTODOS: Estudo transversal de base populacional que envolveu 1.958 idosos residentes em quatro áreas do estado de São Paulo, em 2001/2002. A qualidade de vida foi aferida com o uso do instrumento Medical Outcomes Study SF-36-Item Short Form Health Survey. As oito escalas e os dois componentes do instrumento constituíram as variáveis dependentes e as independentes foram atividade física, freqüência semanal de ingestão de bebida alcoólica e hábito de fumar. Modelos de regressão linear múltipla foram usados para controlar o efeito de sexo, idade, escolaridade, trabalho, área de residência e número de doenças crônicas.

RESULTADOS: Atividade física foi positivamente associada com as oito escalas do SF-36. As maiores associações foram encontradas em aspectos físicos ( $\beta$ $=11,9)$, capacidade funcional $(\beta=11,3)$ e no componente físico. Idosos que ingeriam bebida alcoólica pelo menos uma vez por semana apresentaram melhor qualidade de vida do que os que não ingeriam. Comparados com os que nunca fumaram, os fumantes tiveram pior qualidade de vida no componente mental $(\beta=-2,4)$.

CONCLUSÕES: Os resultados apresentam que praticar atividade física, consumir bebida alcoólica moderadamente e não fumar são fatores positivamente associados a uma melhor qualidade de vida em idosos.

DESCRITORES: Idoso. Qualidade de Vida. Estilo de Vida. Conhecimentos, Atitudes e Prática em Saúde. Estudos Transversais.

\section{INTRODUCTION}

The effects of health-related behavior especially physical activity, smoking and alcohol consumption on the incidence, severity and lethality of diseases are widely recognized. ${ }^{4,6,25}$ The World Health Organization ${ }^{25}$ (WHO, 2009) reports that worldwide $8.7 \%$ of deaths can be attributed to smoking, $5.5 \%$ to physical inactivity and $3.8 \%$ to excessive alcohol consumption. There is sufficient evidence on the numerous harmful effects of tobacco use on health. ${ }^{23,25}$ Physical activity is associated to lower mortality risk and promotes the prevention and control of most chronic diseases.,25 Excess consumption of alcohol increases the risk of several diseases and is associated with increased risk of injuries and violence. ${ }^{19,25}$ On the other hand, moderate alcohol consumption may have a positive effect on health and mortality. ${ }^{3,9,22}$

Despite consistent evidence of the effects of healthrelated behaviors on health, little is known regarding the association between these behaviors and different aspects of quality of life, especially among the elderly.

The few studies investigating the association between health-related quality of life (HRQoL) and healthrelated behaviors have described a positive association between quality of life and physical activity, moderate alcohol consumption and no smoking. ${ }^{1,10,15,20}$ Studies on US adults found a positive association between HRQoL and physical activity in almost all scales of the Medical Outcomes Study SF-36-Item Short Form Health Survey (SF-36). ${ }^{1,11}$ Regarding tobacco use, Cayuela et $\mathrm{al}^{7}$ (2007) and Wilson et $\mathrm{al}^{24}$ (1999) studies found a negative association with HRQoL in smokers compared with never-smokers especially in the role-emotional domain. The association of smoking and mental aspects of HRQoL was reported in Mulder et al study (2001) with adult population in the Netherlands. ${ }^{16}$ Laaksonen et al $(2006)^{10}$ studied a large population sample of the capital of Finland and did not find any significant associations between HRQoL and former smokers or nonsmokers. Another study found the highest scores for some SF-36 scales in adults who moderately consumed alcohol compared with nondrinkers. ${ }^{20}$ Research studies involving the elderly found better functional capacity and mental health among drinkers. ${ }^{6,21}$

The study about this subject in the elderly is relevant given the rapid growth of this population segment due to decreased birth rates and increased life expectancy. ${ }^{5}$ Healthy lifestyles are key to prevent chronic disease and disorder $\mathrm{s}^{25}$ and improve functional capacity and 
well-being especially among the elderly. Besides, they help maintaining their autonomy and independence, allowing an active aging, which is a great public health challenge.

The aim of the present study was to assess the association between HRQoL and health-related behaviors among the elderly.

\section{METHODS}

A population-based cross-sectional study was carried out using data from the Multi-Center Health Survey in the State of São Paulo (ISA-SP), 2001-2002 in four areas of the state of São Paulo, southeastern Brazil: the cities of Botucatu and Campinas; an area covering the cities of Itapecerica da Serra, Embu, and Taboão da Serra; and the district of Butantã in the city of São Paulo.

The sample was obtained through two-stage stratified clustering. Census tracts were grouped into three strata according to the percentage of heads of household with college education: $<5 \% ; 5 \%$ to $25 \%$; and $>25 \%$. Ten census tracts were selected from each stratum totaling 120 sectors in the four areas. Households were selected after updating the maps during fieldwork.

More details on the sampling are published elsewhere. ${ }^{2}$ Briefly, to obtain satisfactory subpopulation sample sizes we defined age domains for both genders: infants less than 1 year of age; children aged 1-11 and 12-19; adults aged 25-59 and 60 years or more. For each domain in each study area minimum sample size of 200 was estimated based on a prevalence of 0.5 , an error of 0.10 , an alpha error of 0.05 and a design effect of 2 . Considering a potential loss of $20 \%, 250$ individuals were selected for each age and gender domain. For obtaining a fixed sample size subsamples of households were randomly selected for each domain. For the elderly domain there were selected 15,750 households in the four areas, 1,600 individuals (200 of each gender in each area). The present study included two domains: men and women aged 60 and more, totaling 1,958 individuals.

Data were collected in a household survey directly from the selected respondent by trained interviewers using a pre-coded questionnaire. The questionnaire comprised closed questions arranged in 19 theme blocks. The SF-36 was used to measure HRQoL.

HRQoL instruments assess the impact of health and disease on social, emotional, physical and mental daily life aspects. They provide sensitive indicators for monitoring disease progression and the effectiveness of therapeutic interventions on the daily performance of patients. ${ }^{a}$ The SF-36 is one of the most widely used instruments to assess HRQoL with 36 questions that provide information on eight domains of health: physical functioning, role-physical (role limitations due to physical health problems), bodily pain, general health (general health perceptions), vitality, social functioning, role-emotional (role limitations due to emotional problems) and mental health. ${ }^{8, a}$ The instrument yields two summary measures: physical component summary (PCS) and mental component summary (MCS). These measures represent behavioral function and dysfunction, distress and well-being, objective reports and subjective ratings, and positive and negative self-evaluations of health status. ${ }^{\text {a }}$ The SF-36 was translated and validated in several languages and cultures including Brazilian Portuguese. ${ }^{8}$

The dependent variables were defined as the scores for the SF-36 eight domains and physical and mental component summary measures.

Each item was scored according to the proposed methodology. Total scores for each of the eight domains were converted to a $0-100$ scale with higher scores representing better health. Differences higher than 5.0 points among the SF-36 mean scores were considered clinically relevant. ${ }^{8, a}$

The independent variables were health-related behaviors: a) leisure-time physical activity obtained using the question "Do you regularly engage in sports or physical activities at least once a week?" and dichotomized into "yes" and "no." The type of physical activity or sport was also analyzed; b) weekly alcohol consumption was categorized as "no consumption," "consumption less than once a week," and "consumption one or more times a week." The type of alcoholic beverage and amount consumed were also evaluated. Alcohol abuse was evaluated using the CAGE (cut down / annoyed / guilty / eye-opener) questionnaire and abuse was ascertained when at least two answers to the four questions were yes; ${ }^{14}$ and c) smoking was categorized as "smoker" (current smoker), "former smoker" (used to smoke at least one cigarette per day every day for at least one month but does not currently smoke) and "non-smoker" (never-smoker). The number of cigarettes smoked per day and time since quitting smoking were also analyzed.

Sociodemographic independent variables included: gender, age (60 to $69 ; 70$ to $79 ; 80$ years or more), schooling ( 0 to $3 ; 4$ to $8 ; 9$ or more years); monthly per capita household income in minimum wages $(<1$; 1 to 4 ; $>4$ ); work status (active, inactive, homemaker); and area of residence (southwest São Paulo; Butantã; Botucatu; Campinas).

Independent variables also included: number of chronic conditions reported from a checklist (hypertension, diabetes, skin disease, allergy, anemia, back pain,

a Ware Jr JE, Kosinski M, Gandek B. 36® Health Survey: Manual and interpretation guide. Lincoln: QualityMetric Incorporated; 2000. 
arthritis, rheumatic disorder, arthrosis, chronic kidney disease, stroke, depression/anxiety, migraine/headache, osteoporosis, cirrhosis, epilepsy, Chagas' disease, Hansen's disease, tuberculosis, schistosomiasis, cancer, heart disease, chronic lung disease, chronic digestive disease) and categorized as $0 ; 1$ or $2 ; 3$ or more.

Categorical variables were transformed in dummy variables for the analyses.

Means, standard error and confidence intervals were estimated for each of the SF-36 scales. Differences in means according to health-related behavior variables were tested using simple linear regression analysis. Multiple regression models were used to control for the effect of gender, age, schooling, income, work status, area of residence and number of chronic conditions. Theses variables have been associated with HRQoL, as observed in previous research studies. ${ }^{12,13}$ Tests were performed to verify whether residual analyses and results were satisfactory.

The analyses were performed using svy commands of Stata 8.0 taking into account the complex sample design of the study - weighting for differential selection probabilities, post-stratification weighting and intra-cluster correlations.

The study was approved by the Research Ethics Committee of Universidade Estadual de Campinas School of Medical Sciences (Protocol no . 079/2007, 15/Dec/2009).

\section{RESULTS}

Among the elderly in the selected households, the rate of losses was $9.4 \%$ (9.1\% due to refusals and $0.3 \%$ due to failure to interview after three attempts). Though non-response rate was greater in higher socioeconomic groups, the differences among the strata were corrected with post-stratification process. The final sample included 1,958 male and female elderly with a mean age of 69.6 years (SD: 0.35).

Table 1 shows that $57.2 \%$ of the population studied were women. Most were between 60 and 69 years of age, had less than four years of schooling with a per capita income of 1 to 4 minimum wages, and were inactive. Most (71\%) did not engage in any leisure-time physical activity, $12 \%$ were smokers and $25 \%$ consumed alcohol at least once a week. Only $13.6 \%$ did not have any chronic condition listed on the study checklist, whereas $45.8 \%$ had three or more diseases.

Table 2 shows a greater prevalence of physical inactivity among women, less educated individuals and with lower income and greater number of chronic conditions. A higher prevalence of alcohol consumption was seen among men aged between 60 and 69 years, those more educated, active and with higher income and those who reported no chronic condition. There were a higher proportion of smokers among men aged 60 to 69 who were active and had a per capita income less than one minimum wage. Although smoking prevalence tended to decrease with an increase in the number of chronic conditions and years of schooling, the differences were not statistically significant.

The most common physical activity (79\%) during leisure time was walking. Among former smokers, $2 \%$

Table 1. Demographic and socioeconomic characteristics of the elderly and prevalence of health-related behaviors. São Paulo, Southeastern Brazil, 2001-2002.

\begin{tabular}{|c|c|c|}
\hline Variable & $\mathrm{n}$ & $\%^{\mathbf{a}}(95 \% \mathrm{Cl})$ \\
\hline \multicolumn{3}{|l|}{ Gender } \\
\hline Male & 929 & $42.7(39.0 ; 46.3)$ \\
\hline Female & 1029 & $57.2(54.9 ; 59.6)$ \\
\hline \multicolumn{3}{|l|}{ Age (years) } \\
\hline $60-69$ & 1092 & $55.8(51.0 ; 60.6)$ \\
\hline $70-79$ & 645 & $33.3(29.1 ; 37.4)$ \\
\hline 80 or more & 221 & $10.8(08.2 ; 13.3)$ \\
\hline \multicolumn{3}{|l|}{ Schooling (years) } \\
\hline $0-3$ & 844 & $42.6(37.4 ; 47.9)$ \\
\hline $4-8$ & 759 & $38.2(34.5 ; 41.4)$ \\
\hline 9 or more & 354 & $19.0(14.7 ; 23.3)$ \\
\hline \multicolumn{3}{|c|}{ Monthly per capita income (minimum wage) } \\
\hline$<1$ & 505 & $23.3(19.6 ; 27.0)$ \\
\hline $1-4$ & 987 & $51.8(48.5 ; 55.2)$ \\
\hline$\geq 4$ & 466 & $24.7(20.6 ; 28.7)$ \\
\hline \multicolumn{3}{|l|}{ Work status } \\
\hline Active & 671 & $33.5(30.1 ; 37.0)$ \\
\hline Inactive & 1084 & $59.3(55.6 ; 63.0)$ \\
\hline Homemaker & 172 & $07.0(05.0 ; 09.1)$ \\
\hline \multicolumn{3}{|l|}{ Leisure-time physical activity } \\
\hline Yes & 612 & $28.8(25.0 ; 32.5)$ \\
\hline No & 1346 & $71.1(67.4 ; 74.9)$ \\
\hline \multicolumn{3}{|l|}{ Smoking } \\
\hline Non-smoker & 1044 & $57.1(53.6 ; 60.6)$ \\
\hline Smoker & 290 & $12.2(09.9 ; 14.5)$ \\
\hline Former smoker & 620 & $30.6(27.9 ; 33.2)$ \\
\hline \multicolumn{3}{|l|}{ Alcohol consumption } \\
\hline No & 1213 & $60.6(56.6 ; 64.6)$ \\
\hline Less than once a week & 244 & $14.0(11.2 ; 16.8)$ \\
\hline One or more times a week & 466 & $25.4(22.1 ; 28.5)$ \\
\hline \multicolumn{3}{|c|}{ Number of chronic conditions (from a checklist) } \\
\hline 0 & 274 & $13.6(11.4 ; 15.8)$ \\
\hline 1 or 2 & 806 & $40.4(37.6 ; 43.33)$ \\
\hline 3 or more & 869 & $45.8(43.5 ; 48.1)$ \\
\hline
\end{tabular}

${ }^{\text {a }}$ Weighted percentages considering the sample design. 
Table 2. Prevalence of health-related behaviors according demographic and socioeconomic variables and number of chronic diseases in the elderly. São Paulo, Southeastern Brazil, 2001-2002.

\begin{tabular}{|c|c|c|c|c|c|c|c|c|c|c|c|}
\hline \multirow[b]{3}{*}{ Variables } & \multicolumn{11}{|c|}{ Health-related behaviors } \\
\hline & \multicolumn{3}{|c|}{ Physical activity (\%) } & \multicolumn{4}{|c|}{ Alcohol consumption (\%) } & \multicolumn{3}{|c|}{ Smoking (\%) } & \multirow[b]{2}{*}{$\mathrm{p}$-value } \\
\hline & No & Yes & $p$-value ${ }^{a}$ & No & $\begin{array}{c}\text { Less } \\
\text { than } \\
\text { once a } \\
\text { week }\end{array}$ & $\begin{array}{c}\text { One or } \\
\text { more } \\
\text { times a } \\
\text { week }\end{array}$ & $\mathrm{p}$-value & $\begin{array}{l}\text { Non- } \\
\text { smoker }\end{array}$ & Smoker & $\begin{array}{l}\text { Former } \\
\text { smoker }\end{array}$ & \\
\hline Gender & & & 0.012 & & & & 0.000 & & & & 0.000 \\
\hline Male & 66.0 & 34.0 & & 48.4 & 12.1 & 39.3 & & 32.8 & 20.2 & 47.0 & \\
\hline Female & 71.2 & 28.8 & & 76.2 & 13.1 & 10.6 & & 72.1 & 10.0 & 17.9 & \\
\hline Age (years) & & & 0.067 & & & & 0.000 & & & & 0.000 \\
\hline $60-69$ & 67.2 & 32.8 & & 58.8 & 12.5 & 28.7 & & 50.2 & 18.3 & 31.5 & \\
\hline $70-79$ & 69.1 & 30.9 & & 66.5 & 12.8 & 20.6 & & 56.7 & 11.3 & 32.0 & \\
\hline 80 or more & 75.1 & 24.9 & & 73.9 & 13.5 & 12.6 & & 59.5 & 8.2 & 32.3 & \\
\hline Schooling (years) & & & 0.000 & & & & 0.000 & & & & 0.092 \\
\hline $0-3$ & 77.1 & 22.9 & & 73.1 & 10.5 & 16.3 & & 50.5 & 15.4 & 34.1 & \\
\hline $4-8$ & 66.8 & 33.2 & & 61.2 & 12.7 & 26.0 & & 56.5 & 15.1 & 28.4 & \\
\hline 9 or more & 53.1 & 46.9 & & 43.4 & 17.7 & 38.9 & & 53.8 & 13.0 & 33.2 & \\
\hline $\begin{array}{l}\text { Income (minimum } \\
\text { wages) }\end{array}$ & & & 0.000 & & & & 0.000 & & & & 0.000 \\
\hline$<1$ & 77.0 & 23.0 & & 70.3 & 12.4 & 17.3 & & 46.9 & 19.6 & 33.5 & \\
\hline $1-4$ & 69.4 & 30.6 & & 65.8 & 10.6 & 23.5 & & 54.1 & 14.5 & 31.4 & \\
\hline$\geq 4$ & 58.4 & 41.6 & & 49.4 & 17.3 & 33.2 & & 59.1 & 10.3 & 30.6 & \\
\hline Work status & & & 0.119 & & & & 0.000 & & & & 0.002 \\
\hline Active & 69.9 & 30.1 & & 55.4 & 12.7 & 31.9 & & 52.4 & 16.1 & 31.5 & \\
\hline Inactive & 67.2 & 32.8 & & 64.9 & 12.8 & 22.3 & & 51.7 & 14.3 & 34.0 & \\
\hline Homemaker & 74.4 & 25.6 & & 79.6 & 12.6 & 7.8 & & 66.3 & 13.9 & 19.8 & \\
\hline $\begin{array}{l}\text { Number of chronic } \\
\text { conditions }\end{array}$ & & & 0.001 & & & & 0.000 & & & & 0.067 \\
\hline 0 & 63.5 & 36.5 & & 43.9 & 15.9 & 40.2 & & 48.3 & 19.8 & 31.9 & \\
\hline 1 or 2 & 65.6 & 34.4 & & 59.4 & 13.3 & 27.3 & & 54.9 & 14.9 & 30.2 & \\
\hline 3 or more & 73.2 & 26.8 & & 73.0 & 11.0 & 16.0 & & 54.0 & 13.1 & 32.9 & \\
\hline
\end{tabular}

quit smoking less than a year prior to the study; $17 \%$ quit between one and five years; and most $(81 \%)$ quit more than six years prior to the study. Among current smokers, $48 \%$ smoked 10 or fewer cigarettes per day and $16 \%$ smoked more than 20 . The most consumed alcoholic beverages were beer $(53 \%)$, wine $(24 \%)$, sugar cane rum (7\%), whiskey (2\%) and other (14\%). Regarding the amount consumed, $72.4 \%$ of beer drinkers consumed $900 \mathrm{~mL}$ or less on a typical day; $100 \%$ of red wine drinkers consumed less than 375 $\mathrm{mL}$ and $90 \%$ of white wine drinkers consumed $300 \mathrm{~mL}$ or less. Among whiskey drinkers, 79\% consumed 125 $\mathrm{mL}$ or less at a time. The CAGE questionnaire revealed that $3.4 \%$ of the entire sample and $8.8 \%$ of those who consumed alcohol tested positive (data not shown).

The mean SF-36 scores and their related standard errors were: 71.4 (1.26) for physical functioning; 81.2 (1.26) for role physical; 74.2 (1.09) for bodily pain; 70.1 (0.86) for general health; 64.4 (1.04) for vitality; 85.9 (1.27) for social functioning; 86.1 (1.16) for role emotional; and 69.9 (0.81) for mental health. The mean PCS and MCS scores and standard errors were 47.6 (0.51) and $44.6(0.37)$ respectively (data not shown).

Table 3 shows that those engaging in physical activities had significantly higher scores for all SF-36 scales compared to those who did not. A positive association was seen with both components with the highest one for the physical component of quality of life $(\beta=3.5)$.

The highest mean SF-36 scores were seen among those who consumed alcohol (Table 4). After adjusting for socioeconomic/demographic variables and chronic conditions, the associations were statistically significant in all SF-36 scales in both categories of alcohol consumption, except for role emotional and social functioning, comparing those who consumed alcohol 
Table 3. Mean scores, confidence intervals and mean differences of SF-36 scales according to leisure-time physical activity. São Paulo, Southeastern Brazil, 2001-2002.

\begin{tabular}{|c|c|c|c|c|}
\hline \multirow[b]{2}{*}{ Scales } & \multirow{2}{*}{$\begin{array}{l}\text { Physical inactivity } \\
\text { (1) } \\
\text { Mean }(95 \% \mathrm{Cl})\end{array}$} & \multirow{2}{*}{$\begin{array}{l}\text { Physical activity (2) } \\
\text { Mean }(95 \% \mathrm{Cl})\end{array}$} & \multicolumn{2}{|c|}{ Mean differences } \\
\hline & & & $\begin{array}{l}\text { Unadjusted }^{\mathbf{a}} \\
\qquad(2-1)\end{array}$ & $\begin{array}{c}\text { Adjusted }^{\mathbf{b}} \\
(2-1)\end{array}$ \\
\hline Physical functioning & $66,9(64.1 ; 69.7)$ & $82.2(76.1 ; 88.3)$ & $15.3 * * *$ & $11.3 * * *$ \\
\hline Role-physical & $76.8(72.6 ; 81.0)$ & $91.5(83.4 ; 99.7)$ & $14.7^{* * *}$ & $11.9 * * *$ \\
\hline Bodily pain & $71.9(69.5 ; 74.3)$ & $79.7(74.1 ; 85.3)$ & $7.8^{* * *}$ & $4.5^{* *}$ \\
\hline General health & $67.7(65.8 ; 69.7)$ & $75.6(71.2 ; 80.1)$ & $7.9 * * *$ & $5.6 * * *$ \\
\hline Vitality & $62.3(60.0 ; 64.5)$ & $69.5(63.7 ; 75.1)$ & $7.2^{* * *}$ & $4.4^{* *}$ \\
\hline Role-emotional & $82.6(79.7 ; 85.6)$ & $94.3(87.8 ; 100)$ & $11.7^{* * *}$ & $9.9 * * *$ \\
\hline Social functioning & $82.7(79.5 ; 86.9)$ & $93.5(86.8 ; 100)$ & $10.8^{* * *}$ & $8.6 * * *$ \\
\hline Mental health & $68.3(66.7 ; 69.9)$ & $73.5(69.3 ; 77.7)$ & $5.2 * * *$ & $2.8^{*}$ \\
\hline Physical component & $46.2(45.1 ; 47.2)$ & $50.9(48.8 ; 53.0)$ & $4.7^{* * *}$ & $3.5^{* * *}$ \\
\hline Mental component & $44.0(43.2 ; 44.9)$ & $46.0(44.0 ; 48.2)$ & $2.0^{* *}$ & $1.3^{*}$ \\
\hline
\end{tabular}

${ }^{*} \mathrm{p}<0.001 ;{ }^{* *} \mathrm{p}<0.010 ;{ }^{* * *} \mathrm{p}>0.05$

a Mean differences of SF-36 score scales (beta coefficients from simple linear regression model).

b Mean differences of SF-36 score scales (beta coefficients) from multiple linear regression model, including gender, age,

schooling, income, work status, area of residence and number of chronic conditions.

less than once a week and those who did not. Both PCS and MCS also showed associations with both categories of alcohol consumption.

Table 5 shows that smokers had lower scores for the role-emotional $(\beta=-6.2)$ and mental health $(\beta=-5.7)$ domains than non-smokers after adjusting for socioeconomic and demographic variables and chronic conditions. Considering the mean scores for the scale's two components, a significant association was seen only for the mental component when smokers were compared to non-smokers $(\beta=-2.4)$.

\section{DISCUSSION}

Significant associations were found between healthrelated behaviors (leisure-time physical activity, alcohol consumption and smoking) and HRQoL. Compared to physical inactive individuals those elderly who engaged in physical activity had better HRQoL for both the physical and mental components, especially for the role-physical and physical functioning dimensions. Better HRQoL was seen among alcohol drinkers compared to non-drinkers. As for smoking, there was a statistically significant association only for the mental

Table 4. Mean scores, confidence intervals and mean differences of SF-36 scales according to alcohol consumption. São Paulo, Southeastern Brazil, 2001-2002.

\begin{tabular}{|c|c|c|c|c|c|c|c|}
\hline \multirow[b]{2}{*}{ Scales } & \multirow[b]{2}{*}{$\begin{array}{c}\text { No consumption } \\
\text { (1) } \\
\text { Mean }(95 \% \mathrm{Cl})\end{array}$} & \multicolumn{2}{|c|}{ Alcohol consumption } & \multicolumn{2}{|c|}{$\begin{array}{l}\text { Unadjusted } \\
\text { differences }^{\mathbf{a}}\end{array}$} & \multicolumn{2}{|c|}{$\begin{array}{c}\text { Adjusted } \\
\text { differences }\end{array}$} \\
\hline & & $\begin{array}{c}\text { Less than once a } \\
\text { week }(2) \\
\text { Mean }(95 \% \mathrm{Cl})\end{array}$ & $\begin{array}{c}\text { One or more } \\
\text { times a week }(3) \\
\text { Mean }(95 \% \mathrm{Cl})\end{array}$ & $(2-1)$ & $(3-1)$ & $(2-1)$ & $(3-1)$ \\
\hline Physical functioning & $65.8(62.9 ; 68.7)$ & $76.7(69.4 ; 83.9)$ & $82.1(76.0 ; 83.9)$ & $10.9^{*}$ & $16.3^{*}$ & $6.8^{* *}$ & $5.9 * *$ \\
\hline Role-physical & $75.7(71.8 ; 79.7)$ & $87.1(77.6 ; 96.7)$ & $90.0(82.0 ; 98.1)$ & $11.4^{*}$ & $14.3^{*}$ & $6.4^{* * *}$ & $8.3^{*}$ \\
\hline Bodily pain & $70.3(68.0 ; 72.6)$ & $79.1(72.7 ; 85.5)$ & $80.4(75.6 ; 85.1)$ & $8.8^{*}$ & $10.1^{*}$ & $5.0^{* *}$ & $2.8^{* * *}$ \\
\hline General health & $66.1(63.7 ; 68.5)$ & $77.6(71.6 ; 83.6)$ & $74.9(69.2 ; 80.5)$ & $11.5^{*}$ & $8.8^{*}$ & $7.9^{*}$ & $3.3 * * *$ \\
\hline Vitality & $59.2(56.6 ; 61.8)$ & $71.8(65.4 ; 78.2)$ & $71.9(65.8 ; 78.0)$ & $12.6^{*}$ & $12.7^{*}$ & $8.5^{*}$ & $6.9^{*}$ \\
\hline Role-emotional & $82.3(79.4 ; 85.3)$ & $87.3(80.5 ; 94.2)$ & $93.0(87.2 ; 98.9)$ & $5.0 * * *$ & $10.7^{*}$ & 3.4 & $5.1 * * *$ \\
\hline Social functioning & $82.1(79.0 ; 85.1)$ & $89.6(80.3 ; 98.8)$ & $93.4(86.7 ; 100.0)$ & $7.5^{* * *}$ & $11.3^{*}$ & 3.1 & $6.2^{*}$ \\
\hline Mental health & $66.4(64.3 ; 68.5)$ & $76.0(70.1 ; 81.9)$ & $74.3(69.0 ; 79.6)$ & $9.6^{*}$ & $7.9^{*}$ & $6.1 * *$ & $3.4 * * *$ \\
\hline Physical component & $45.7(44.5 ; 46.8)$ & $49.8(47.4 ; 52.2)$ & $50.8(48.5 ; 53.1)$ & $4.1^{*}$ & $5.1^{*}$ & $2.6^{*}$ & $1.9 * *$ \\
\hline Mental component & $43.3(42.2 ; 44.3)$ & $46.8(43.6 ; 50.0)$ & $46.8(43.8 ; 49.0)$ & $3.5^{* *}$ & $3.1^{*}$ & $2.1 * * *$ & $1.7 * * *$ \\
\hline
\end{tabular}

${ }^{*} \mathrm{p}<0.001 ;{ }^{* *} \mathrm{p}<0.010 ;{ }^{* * *} \mathrm{p}<0.05$

a Mean differences of SF-36 score scales (beta coefficients from simple linear regression model).

b Mean differences of SF-36 score scales (beta coefficients) from multiple linear regression model, including gender, age, schooling, income, work status, place of residence and number of chronic conditions. 
Table 5. Mean scores, confidence intervals and mean differences of SF-36 scales according to smoking. São Paulo, Southeastern Brazil, 2001-2002.

\begin{tabular}{|c|c|c|c|c|c|c|c|}
\hline \multirow{2}{*}{ Scales } & \multicolumn{3}{|c|}{ Smoking } & \multicolumn{2}{|c|}{$\begin{array}{l}\text { Unadjusted } \\
\text { differences }^{\mathrm{a}}\end{array}$} & \multicolumn{2}{|c|}{$\begin{array}{l}\text { Adjusted } \\
\text { differences }{ }^{b}\end{array}$} \\
\hline & $\begin{array}{l}\text { Non-smoker }(1) \\
\text { Mean }(95 \% \mathrm{Cl})\end{array}$ & $\begin{array}{c}\text { Smoker }(2) \\
\text { Mean }(95 \% \mathrm{Cl})\end{array}$ & $\begin{array}{c}\text { Former smoker }(3) \\
\text { Mean }(95 \% \mathrm{Cl})\end{array}$ & $(2-1)$ & $(3-1)$ & $(2-1)$ & $(3-1)$ \\
\hline Physical functioning & $70.4(67.1 ; 73.7)$ & $73.9(64.9 ; 83.0)$ & $72.3(65.4 ; 79.2)$ & 3.5 & 1.9 & -1.1 & 0.4 \\
\hline Role-physical & $83.4(79.0 ; 87.7)$ & $81.9(70.3 ; 93.4)$ & $76.7(67.4 ; 86.0)$ & -1.5 & $-6.7 *$ & -1.1 & -4.2 \\
\hline Bodily pain & $75.1(72.5 ; 77.7)$ & $75.3(68.3 ; 81.9)$ & $73.6(65.5 ; 76.8)$ & 0.2 & -1.5 & -1.7 & -3.2 \\
\hline General health & $69.7(67.3 ; 72.0)$ & $70.5(64.4 ; 76.7)$ & $70.6(64.9 ; 67.7)$ & 0.8 & 0.9 & 0.06 & 1.8 \\
\hline Vitality & $63.7(61.1 ; 66.2)$ & $66.0(59.4 ; 72.6)$ & $65.0(59.4 ; 70.7)$ & 2.3 & 1.3 & 0.3 & 0.7 \\
\hline Role-emotional & $86.8(83.9 ; 89.7)$ & $83.2(75.1 ; 91.2)$ & $86.1(78.4 ; 93.6)$ & -3.6 & -0.7 & $-6.2 * *$ & -1.6 \\
\hline Social functioning & $86.1(83.4 ; 88.7)$ & $85.2(78.8 ; 91.5)$ & $85.5(79.8 ; 92.2)$ & -0.9 & -0.6 & -1.3 & 0.1 \\
\hline Mental health & $70.0(67.8 ; 72.2)$ & $65.9(59.5 ; 72.3)$ & $71.2(66.2 ; 76.2)$ & -4.1 & 1.2 & $-5.7 * * *$ & 0.2 \\
\hline Physical component & $47.5(46.2 ; 48.9)$ & $49.0(45.7 ; 52.5)$ & $47.0(44.1 ; 49.8)$ & 1.5 & -0.5 & 0.6 & -0.3 \\
\hline Mental component & $44.7(43.7 ; 45.7)$ & $43.0(40.1 ; 45.9)$ & $45.1(42.7 ; 47.6)$ & -1.7 & 0.4 & $-2.4 * * *$ & -0.04 \\
\hline
\end{tabular}

* $\mathrm{p}<0.001 ;{ }^{* *} \mathrm{p}<0.05 ; * * * \mathrm{p}<0.010$

a Mean differences of SF-36 score scales (beta coefficients from simple linear regression model).

b Mean differences of SF-36 score scales (beta coefficients) from multiple linear regression model, including gender, age,

schooling, income, work status, place of residence and number of chronic conditions.

component of quality of life, and smokers showed poorer quality of life than never-smokers.

The results of the present study are consistent with those of other studies using the SF-36 that found a positive association between physical activity and HRQoL. Acree et $\mathrm{al}^{1}$ (2006) studied 112 elderly in Oklahoma (US) and when individuals with low and high levels of physical activity were compared they found significant differences in mean scores for all SF-36 scales, except for general health, role emotional and mental health. Laforge et $\mathrm{al}^{11}$ (1999) investigated adults in Rhode Island (US) and compared different levels of physical activity (from intention to engage in a physical activity to ongoing activity for more than six months). They found positive differences in the mean scores for all SF-36 scales, except for social functioning. As occupations in urban centers are increasingly associated to low levels of human movement and the elderly are less economically active, leisure-time physical activity is an adequate indicator for measuring physical activity in this population. ${ }^{26}$ It should be noted that among those reporting being physically active, some may be insufficiently active.

The weekly frequency of alcohol consumption was positively associated with better HRQoL in all SF-36 scales, except for role emotional and social functioning comparing those who consumed alcohol less than once a week with those who did not. A study carried out in Japan using the SF-36 in a large adult population found that those who consumed alcohol once or twice a week had better quality of life, as expressed in the vitality and mental health scales, compared to those who did not, even after adjusting for confounders. ${ }^{20}$ Santos et $\mathrm{al}^{21}$ (2008) studied elderly individuals in the city of São
Paulo, Brazil, with data from the study (SABE ProjectSaúde, Bem-estar e Envelhecimento [Health, Wellbeing and Aging Project]), and found that those who did not consume alcohol were more likely (adjusted odds ratio) to have difficulties in performing daily living activities. Rodgers et $\mathrm{al}^{19}$ (2000) investigated 2,725 adults and found higher rates of depression and anxiety among those who did not consume or only occasionally consumed alcohol when compared to those who moderately consumed it. Moreover, excessive alcohol consumption has a negative effect on these conditions. Alcohol dependence and abuse can have harmful health consequences in terms of increased risk of disease and increased risk of injuries and violence. ${ }^{25}$ However, moderate alcohol consumption can have a positive effect on health and mortality. ${ }^{9,22,25}$

In the present study, alcohol consumption was positively associated with HRQoL. Moreover, alcohol consumption was generally not excessive or abusive as revealed by the low rate of positive CAGE results and low amounts of alcohol consumed that were mostly below moderate levels. ${ }^{9}$ The most consumed alcoholic beverages were beer and wine. A previous study has reported that both beer and wine have a greater association with better HRQoL compared to distilled alcoholic beverages. ${ }^{22}$

Smokers showed lower mean scores of quality of life only for the MCS, particularly for the role-emotional and mental health domains when compared to neversmokers. Similar findings were reported by Mulder et $\mathrm{al}^{16}$ (2001) in the Netherlands who found a stronger association for the mental domain. In a cohort study carried out in Spain with 240 men, Cayuela et $\mathrm{al}^{7}$ (2007) found lower mean SF-36 scores among smokers 
compared to non-smokers especially for the roleemotional domain (mean difference of 14 points). In the present study, $48 \%$ of the smokers consumed less than 10 cigarettes per day, which may suggest a less negative effect on HRQoL. Survival bias should be also considered as heavy smokers have greater risk of premature death and would be less likely to be among the elderly population studied.

No associations were seem when former smokers were compared to never-smokers in the present study. Using data from the South Australian Health Omnibus Survey on adults, Wilson et $\mathrm{al}^{24}$ (1999) found lower scores among former smokers compared to non-smokers for five of the eight SF-36 scales with the greatest differences for the general health and role-physical domains. Previous studies did not find significant associations when comparing former smokers with non-smokers. ${ }^{10,16}$ Most former smokers in the present study (81\%) quit smoking more than six years prior to the survey. Quitting smoking reduces the risk of disease, increases life expectancy of those with illnesses and improves quality of life, though the harmful effects of smoking lasts for a certain amount of time depending on the health condition. ${ }^{16,23}$ For instance, it may take about 10 to 30 years for former smokers' risk of lung cancer to reach that of never smokers. ${ }^{23}$ Age and the emergence of chronic diseases lead to subsequent reduction in quality of life and have been associated to smoking cessation. ${ }^{17}$ However, the analyses in the present study were adjusted for the number of reported morbidities to avoid confounding.

Among the three health-related behaviors studied, physical activity had the strongest association with HRQoL for all SF-36 domains among those who did and did not engage in physical activities. Pimenta et al

\section{REFERENCES}

1. Acree LS, Longfors J, Fjeldstad AS, Fjeldstad C, Schank B, Nickel KJ, et al. Physical activity is related to quality of life in older adults. Health Qual Life Outcomes. 2006;4:37-43. DOI:10.1186/1477-7525-4-37

2. Alves MCGP. Plano de Amostragem. In: César CLG, Carandina L, Alves MCGP, Barros MBA, Goldbaum M. Saúde e condição de vida em São Paulo. Inquérito multicêntrico de saúde no Estado de São Paulo. ISA-SP. São Paulo: Faculdade de Saúde Pública- USP; 2005. p. 47-62.

3. Bridevaux IP, Bradley KA, Bryson CL, McDonell MB, Fihn SD. Alcohol screening. Results in elderly male veterans: association with health status and mortality. J Am Geriatr Soc. 2004;52(9):1510-7. DOI:10.1111/ j.1532-5415.2004.52414.x

4. Byberg L, Melhus H, Gedeborg R, Sundström J, Ahlbom A, Zethelius B, et al. Total mortality after changes in leisure time physical activity in 50 year old men: 35 year follow-up of population based cohort. $\mathrm{Br}$ J Sports Med. 2009;43(7):482-90.
(2008) found similar results among 87 retirees in Brazil while studying HRQoL based on these three behaviors. ${ }^{18}$

The cross-sectional design is a limitation of this study as it does not allow identifying causality. Health-related behaviors may influence quality of life in the elderly or, considering a reverse causality, the elderly with good health and well-being are able to adopt and maintain healthy behaviors. There is a need for further investigation to better assess these associations. Another limitation of the present study is the use of secondary data with poor detailing on physical activity and reduced number of individuals reporting excessive alcohol consumption. Nevertheless, the categories studied were sufficient to detect the associations.

The importance of this study is reinforcing the findings of the international researches about this theme, increasing information which are scarce for elderly population. This research shows results unpublished in Brazil, analyzing the association of the health behavior with the several quality of life dimensions in elderly, using the SF-36 instrument, in a population-based study.

Health promotion actions such as promoting leisuretime physical activity and other healthy behaviors should take into consideration social inequalities in the prevalence of health-related behaviors.

In view of the demographic and epidemiological transition, the number of elderly in Brazil and worldwide has been rapidly growing and there have been significant gains in life expectancy. ${ }^{5}$ Thus, control interventions should be carried out to reduce the consequences and limitations of diseases. Moreover, health promotion actions improving well-being, functional capacity and mental health of the elderly are needed along with studies to monitor their quality of life.

5. Carvalho JAM, Garcia RA. O envelhecimento da população brasileira: um enfoque demográfico. Cad Saude Publica. 2003;19(3):725-33. DOI: 10.1590/ S0102-311X2003000300005

6. Cassidy K, Kotynia-English R, Acres J, Flicker L, Lautenschlager NT, Almeida OP. Association between lifestyle factors and mental health measures among community-dwelling older women. Aust N Z J Psychiatry. 2004;38(11-12):940-7.

7. Cayuela A, Rodríguez-Domínguez S, Otero R. Deterioro de la calidad de vida relacionada con la salud en fumadores varones sanos. Arch Bronconeumol. 2007;43(2):59-63. DOI:10.1016/ S1579-2129(07)60025-1

8. Ciconelli RM, Ferraz MB, Santos W, Meinão I, Quaresma MR. Tradução para a língua portuguesa e validação do questionário genérico de avaliação de qualidade de vida SF-36 (Brasil SF-36). Rev Bras Reumatol. 1999;39(3):143-50. 
9. Klatsky AL. Moderate drinking and reduced risk of heart disease. Alcohol Res Health. 1999;23(1):15-23.

10. Laaksonen M, Rahkonen O, Martikainen P, Karvonen S, Lahelma E. Smoking and SF-36 health functioning. Prev Med. 2006;42(3):206-9. DOI:10.1016/j. ypmed.2005.12.003

11. Laforge RG, Rossi JS, Prochaska JO, Velicer WF, Levesque DA, McHorner CA. Stage of Regular Exercise and Health-Related Quality of Life. Prev Med. 1999;28(4):349-60. DOI:10.1006/pmed.1998.0429

12. Lima MG, Barros MBA, César CLG, Goldbaum M, Carandina L, Ciconelli R M. Health related quality of life among the elderly: a population-based study using SF-36 survey. Cad Saude Publica. 2009;25(10):215967. DOI:10.1590/S0102-311X2009001000007

13. Lima MG, Barros MBA, César CLG, Carandina L, Goldbaum M. Impact of chronic disease on quality of life among the elderly in the state of São Paulo, Brazil: a population-based study. Rev Panam Salud Publica. 2009;25(4):314-21. DOI:10.1590/S102049892009000400005

14. Masur J, Monteiro MJ. Validation of the "CAGE" alcoholism screening test in a Brazilian psychiatric inpatient hospital setting. Braz / Med Biol Res. 1983;16(3):215-8.

15. Mitra M, Chung M, Wilber N, Walker DK. Smoking status and quality of life. A longitudinal study among adults with disabilities. Am / Prev Med. 2004;27(3):258-60. DOI:10.1016/S07493797(04)00125-4

16. Mulder I, Tijhuis M, Smit HA, Kromhout D. Smoking Cessation and quality of life: the effect of amount of smoking and time since quitting. Prev Med. 2001; 33(6):653-60. DOI:10.1006/pmed.2001.0941

17. Peixoto SV, Firmo JOA, Lima-Costa MF. Fatores associados ao índice de cessação do hábito de fumar em duas diferentes populações adultas (Projetos Bambuí e Belo Horizonte). Cad Saude Publica. 2007;23(6):1319-28. DOI:10.1590/S0102$311 \times 2007000600007$
18. Pimenta FAP, Simil FF, Tôrres HOG, Amaral CFS, Rezende CF, Coelho TO, et al. Avaliação da qualidade de vida de aposentados com a utilização do questionário sf-36. Rev Assoc Med Bras. 2008;54(1):55-60.

19. Rodgers B, Korten AE, Jorm AF, Christensen $H$, Henderson S, Jacomb PA. Risk factors for depression and anxiety in abstainers, moderate drinkers and heavy drinkers. Addiction. 2000;95(12):1833-45. DOI:10.1046/j.1360-0443.2000.9512183312.x

20. Saito I, Okamura T, Fukuhara S, Tanaka T, Suzukamo Y, Okayama A, et al. A cross-sectional study of alcohol drinking and health-related quality of life among male workers in Japan. J Occup Health. 2005;47(6):496503. DOI:10.1539/joh.47.496

21. Santos JLF, Lebrão ML, Duarte YAO, Lima FD. Functional performance of the elderly in instrumental activities of daily living: an analysis in the municipality of São Paulo, Brazil. Cad Saude Publica. 2008;24(4):879-86. DOI:10.1590/S0102311X2008000400019

22. Stranberger TE, Stranberger AY, Salomaa VV, Pitka K, Tilvis RS, Miettnen TA. Alcoholic beverage preference, 29-year mortality, and quality of life in men in old age. J Gerontol A Biol Sci Med Sci. 2007;62(2):213-18.

23. Westmaas JL, Bandon TH. Reducing risk in smokers. Curr Opin Pulm Med. 2004;10(4):284-8. DOI:10.1097/01.mcp.0000128431.72268.4d

24. Wilson D, Parsons J, Wakefield M. The health-related quality-of-life of never smokers, ex-smokers, and light, moderate, and heavy smokers. Prev Med. 1999;29(3):139-44. DOI:10.1006/pmed.1999.0523

25. World Health Organization. Global health risks: mortality and burden of disease attributable to selected major risks: Geneva; 2009.

26. Zaitune MPA, Barros MBA, César CLG, Carandina L, Goldbaum M. Fatores associados ao sedentarismo no lazer em idosos, Campinas, São Paulo, Brasil. Cad Saude Publica. 2007;23(6):1329-38. DOI:10.1590/ S0102-311X2007000600008

The authors declare that there are no conflicts of interests. 